\title{
Systemic prepartum treatment of end-term dairy heifers with penethamate hydriodide: Effect on udder health, milk yield, and culling until 120 days in milk
}

\author{
P. Passchyn, ${ }^{*} \dagger^{1}$ S. Piepers, $\dagger$ and S. De Vliegher $†$ \\ *Independent Dairy Consultant, Milk@vice, 8820 Torhout, Belgium \\ †M-team and Mastitis and Milk Quality Research Unit, Department of Reproduction, Obstetrics, and Herd Health, Faculty of Veterinary Medicine, \\ Ghent University, 9820 Merelbeke, Belgium
}

\begin{abstract}
Prepartum intramammary treatment with antimicrobials of end-term dairy heifers has frequently been proposed as a practice to reduce the prevalence of intramammary infections (IMI) at calving. From a safety standpoint for both animal and administrator, systemic treatment is preferred. A clinical trial was conducted on heifers from 10 well-managed, commercial dairy farms with a low prevalence of heifer mastitis. The aim was to assess both the short- and long-term effects of a systemic prepartum therapy with penethamate hydriodide on udder health and milk production. Because it was hypothesized that some herds would benefit more from this treatment than others, specific herd-level information was collected before the start of the actual trial to screen for and explain potential herd-specific treatment effects. Further, the effect of treatment on antimicrobial susceptibility of staphylococcal isolates was monitored. End-term heifers were either treated systemically (over 3 consecutive days) 2 wk before expected calving date with penethamate hydriodide $(\mathrm{n}=76)$ or remained untreated $(\mathrm{n}=73)$. Systemic prepartum treatment of end-term heifers with penethamate hydriodide resulted in fewer IMI in early lactation. However, all 6 cases of clinical mastitis in early lactation occurred in the treatment group [Streptococcus uberis $(\mathrm{n}=1)$, Corynebacterium bovis $(\mathrm{n}=1)$, Staphylococcus aureus $(\mathrm{n}=$ 1); 1 sample was contaminated; 2 samples remained culture negative]. No long-term treatment effects (from 4 to $120 \mathrm{~d}$ in milk) on milk production, udder health, or culling hazard during later lactation were detected, although treated heifers belonging to herds classified as having low-yielding heifers out-produced the control heifers. Moreover, penicillin susceptibility of staphylococci isolated from milk samples of treated or control heifers did not differ. Herds with a low prevalence of
\end{abstract}

Received January 27, 2013

Accepted June 23, 2013

${ }^{1}$ Corresponding author: pieter.passchyn@telenet.be heifer mastitis are not likely to benefit from prepartum systemic antimicrobial treatment of the end-term heifers.

Key words: clinical trial, heifer mastitis, penethamate hydriodide, prepartum treatment

\section{INTRODUCTION}

Generally, bred heifers are assumed to have no issues with udder health and for that reason their mammary glands and secretions are often not checked until calving (Nickerson, 2009). However, a large proportion of dairy heifers calve with infected quarters (Fox, 2009). Studies have shown a wide variation in prevalence, from 29.0 to $74.6 \%$ (Oliver and Mitchell, 1983; Trinidad et al., 1990a) and from 12.3 to $55.0 \%$ (Roberson et al., 1994; Parker et al., 2007) of quarters being reported as culture positive before and at calving, respectively. Several different pathogens have been isolated but studies have shown that infections are predominantly caused by gram-positive bacteria, specifically CNS, Staphylococcus aureus, and environmental streptococci (Fox, 2009). Heifer mastitis can have a negative effect on future productive life (De Vliegher et al., 2004, 2005a,b), the effect depending on factors such as virulence of the pathogens involved and time of onset of the IMI during gestation (Piepers et al., 2009). The cost of subclinical heifer mastitis in early lactation alone on an average Dutch or Flemish dairy farm has been estimated to vary from $€ 4$ to $€ 82$ per heifer with an average of $€ 31$ (Huijps et al., 2009).

The use of prepartum antimicrobial treatment of endterm heifers in the control of heifer mastitis has been studied using short-acting intramammary preparations, administered between 6 and $21 \mathrm{~d}$ before calving. (Oliver et al., 1992, 2004; Middleton et al., 2005; Borm et al., 2006; Roy et al., 2007) and long-acting intramammary preparations, administered between 0 and $270 \mathrm{~d}$ before calving (Trinidad et al., 1990b; Owens et al., 1991, 1994, 2001; Sampimon et al., 2009). The majority of those studies showed positive effects in the short term, 
as seen by higher cure rates of IMI detected before calving and a lower prevalence of IMI at calving in treated heifers compared with untreated controls (Nickerson, 2009). One could argue that it makes more sense from an economical point of view to study the treatment effects in the longer term rather than in the short term. Trinidad et al. (1990b) studied milk production during the first 2 mo of lactation and showed that Staph. aureus-infected heifers that had received prepartum dry cow therapy (penicillin and dihydrostreptomycin) produced an average of $2.5 \mathrm{~kg}$ more milk per day than Staph. aureus-infected herdmates that did not receive treatment. Oliver et al. (2004) showed that prepartum intramammary treatment using short-acting preparations (penicillin-novobiocin and pirlimycin hydrochloride) was effective in reducing the percentage of infected heifers and quarters during the first 30 DIM, whereas Sampimon et al. (2009) reported positive long-term effects of dry cow antimicrobial (cloxacillin) treatment 8 to 10 wk before the expected calving date on the incidence of clinical mastitis (CM), test-day SCC, and test-day milk yield (MY) in first lactation. The study of Oliver et al. (2004) is contrasted with the findings of Middleton et al. (2005), who observed that intramammary treatment using short-acting preparations (pirlimycin hydrochloride) did not necessarily reduce SCC or result in higher milk production during the first lactation, although a higher overall cure rate at calving was noted.

Borm et al. (2006) concluded, based on the results of milk production, that prepartum treatment of endterm heifers with short-acting intramammary preparations (cephapirin) was not uniformly efficacious across herds, but potential herd-level factors explaining the findings were not studied further. Bryan and Taylor (2009) also reported a strong herd effect in their study, demonstrating that systemic treatment with a single large dose of intramuscular penicillin within $12 \mathrm{~h}$ after calving was successful in significantly reducing the incidence of CM in heifers within the first 7 DIM. Given these results, use of prepartum antimicrobial therapy in end-term heifers, as a universal and economical viable strategy to increase milk production and improve udder health in heifers, is not warranted. However, because some herds seem to benefit from treatment and others do not, it would be useful to understand why this is and what kind of factors are associated with that finding, specifically in the light of prudent and substantiated use of antimicrobials.

Systemic antimicrobial treatment of end-term heifers has several advantages over intramammary treatment: a lower risk of teat contamination, a higher convenience and safety to administer, and 4 quarters being treated with a single administration. Systemic use of penetha- mate hydriodide before calving was associated with penicillin $G$ levels in mammary tissue and secretion substantially higher than the $\mathrm{MIC}_{90}$ (the concentration required to inhibit growth of $90 \%$ of the organisms) of pathogens associated with heifer mastitis (Passchyn et al., 2010). However, the limited number of studies that have looked at systemic treatment showed either no effect (Parker et al., 2008; using tylosin) or a positive effect and were only conducted on problem herds (Kreiger et al., 2007; using penethamate hydriodide).

Antimicrobial agents are necessary for decreasing the prevalence and incidence of bacterial diseases in animals. Their use in veterinary medicine can have a positive effect on animal health, animal well-being, and productivity when used with sound clinical judgment combined with sound management practices (Johnston, 1998). Excessive or injudicious use of antimicrobials should, however, be avoided at all time. Given the recent concerns related to the emergence of antimicrobial resistance in human and animal pathogens and the possible link with the use of antimicrobials in livestock, monitoring the development of antimicrobial resistance, even in the short term, in treatment trials obviously reflects good practice. Antimicrobial resistance of udder pathogens in Belgium (Annual Report 2011, Milk Control Centre Flanders, Lier, Belgium) is low and in line with that in other countries (Erskine, 2006).

A clinical trial was conducted on heifers from 10 well-managed, commercial dairy farms with a low prevalence of heifer mastitis. The aim was to assess both the short-term and long-term effects of a systemic prepartum therapy with penethamate hydriodide $2 \mathrm{wk}$ before the expected date of calving on udder health and milk production. Because it was hypothesized that some herds would benefit more from this treatment than others, herd-level information was collected before the start of the actual trial to screen for and explain any herd-specific treatment effect. Further, the effect of treatment on susceptibility of staphylococcal isolates from milk was monitored.

\section{MATERIALS AND METHODS}

\section{Herds, Heifers, and Study Design}

The study was conducted between September 2008 and June 2010 and included 229 heifers from 10 commercial dairy herds, located in a radius of $20 \mathrm{~km}$ around Torhout, in the province of West Flanders, Belgium (Table 1). In total, 80 heifers served as monitoring heifers, 76 heifers were treated, and 73 were untreated control heifers. Herd owners were approached by the first author and asked whether they were willing to participate. All herds had a good animal identification 
system, participated in the local DHI program (CRV, Oosterzele, Belgium) on a 4- to 6-weekly basis, and kept good records of treatments and diseases. Herds already treating end-term heifers with antimicrobial agents before calving were not approached.

Herd size ranged from 45 to 118 lactating cows with an average milk production of $9,220 \mathrm{~kg} / \mathrm{cow}$ per lactation, ranging from 8,154 to $11,122 \mathrm{~kg} /$ cow. The geometric mean of the bulk milk SCC per herd in the 6-mo period before the study started was 226,000 cells/ $\mathrm{mL}$, ranging from 74,000 to 326,000 cells $/ \mathrm{mL}$. None of the herds reported a heifer mastitis problem, and none of the herds was considered to have such a problem when comparing the CM and SCC herd data using the thresholds published earlier [herd suffering from heifer mastitis if $>15 \%$ of heifers have CM around calving or if $>15 \%$ of all heifers have a first test-day SCC (measured between 10 and 35 DIM) >150,000 cells/mL; De Vliegher et al., 2012]. All lactating cows and heifers were housed in freestalls with cubicles and sawdust was used as bedding material in all herds.

Before the actual trial started, herds were first monitored by sampling the first 8 heifers per herd that calved ( 80 heifers in total) to construct several binomial herd-level predictor variables (Table 2). Milk samples were taken between 0 and 3 DIM for SCC measurement (composite milk) and bacteriological culture (quarter milk) as mentioned below. Monitoring of a herd ended after the eighth heifer had calved. Thereafter, the actual clinical trial started for this herd, comprising approximately an additional 16 heifers, of which half were treated before calving and half served as untreated controls. Heifers were alternately assigned by the first author based on their expected calving date; every other heifer that was expected to calve was treated with penethamate. No placebo was used in the untreated control group. In total, we aimed for 160 heifers, belonging to 10 herds (16 per herd), to be included in the actual treatment trial based on a sample size calculated using an expected difference in the proportion of infected animals in early lactation of $20 \%$ between the untreated and treated group [level of confidence 95\%, power 80\%; WinEpiscope 2.0; Computer-Aided Learning in Veterinary Education (CLIVE), University of Edinburgh, UK].

\section{Treatment Regimen}

As mentioned, approximately 8 end-term heifers per herd were treated systemically approximately $14 \mathrm{~d}$ (median $13.8 \mathrm{~d}$; interquartile range 10 to $16 \mathrm{~d}$ ) before the expected calving date, and another 8 heifers per herd served as untreated controls. Heifers were only included if they were clinically healthy at the time of poten- tial treatment and had not received any antimicrobial treatment in the last $4 \mathrm{wk}$ before treatment; heifers were excluded from the study if they calved within $3 \mathrm{~d}$ after treatment. Treatment consisted of daily i.m. injections of penethamate hydriodide (Mamyzin Stop M, Boehringer Ingelheim GmbH, Ingelheim, Germany) for 3 consecutive days at a dose of $10 \mathrm{~g} /$ animal on the first day, followed by $5 \mathrm{~g} /$ animal on the second and third days $(1 \mu \mathrm{g}$ of penethamate hydriodide provides $1 \mathrm{IU}$ of penicillin G), in accordance with the approved commercial product label for France. Mamyzin is registered in Belgium for treatment of clinical and subclinical mastitis in lactating cows, meaning that treatment of end-term heifers with Mamyzin constitutes extra-label use. Extra-label use is allowed in Belgium under specific conditions and with implications for the withholding time of both meat and milk. All treatments were administered by the farmer.

\section{Data and Sampling}

All heifers were sampled by the first author once between 0 to 3 DIM (hereafter referred to as early lactation) for bacteriological culture $(5 \mathrm{~mL}$; duplicate quarter milk samples) and determination of milk SCC (30, mL; composite sample: samples of different quarters were combined using equal volumes), and were checked for signs of CM at that time. All milk samples were collected after disinfection of the teats and after the first streams of milk were discarded. Milk samples were immediately stored at $4^{\circ} \mathrm{C}$ and then transported under cooled conditions to the laboratory (Milk Control Centre Flanders, Lier, Belgium).

Data on the occurrence of CM, culling, and the reason for culling during the first 120 DIM were recorded by the farmer. Milk recording data (test-day milk production and composite SCC) of all heifers were collected at an interval of 4 to $6 \mathrm{wk}$ until 120 DIM.

\section{Laboratory Analyses}

Bacteriological Culture. Bacteriological culture was done as described previously (Piepers et al., 2007). Briefly, $0.01 \mathrm{~mL}$ of milk was plated on a blood-esculin agar (Oxoid, Erembodegem, Belgium; 1 plate per cow) and on MacConkey agar (Oxoid; 1 plate per cow). All plates were incubated aerobically for $36 \pm 12 \mathrm{~h}$ at 37 $\pm 1^{\circ} \mathrm{C}$. A quarter was considered culture-positive when growth of $\geq 1$ colony was detected. Samples yielding 3 or more different bacterial species were considered to be contaminated. Bacteria were identified by colony morphology and Gram staining. For gram-positive cocci, catalase tests were used to differentiate between catalase-positive staphylococci and catalase-negative 
Table 1. Overview of herd characteristics and management practices in the 10 commercial dairy herds participating in the study

\begin{tabular}{|c|c|c|c|c|c|c|c|c|c|c|}
\hline \multirow{2}{*}{$\begin{array}{l}\text { Herd characteristic } \\
\text { or management practice }\end{array}$} & \multicolumn{10}{|c|}{ Herd } \\
\hline & 1 & 2 & 3 & 4 & 5 & 6 & 7 & 8 & 9 & 10 \\
\hline Average lactating cows (no.) & 118 & 54 & 58 & 51 & 45 & 64 & 86 & 83 & 65 & 62 \\
\hline $305-\mathrm{d}$ milk yield $(\mathrm{kg})$ & 9,271 & 8,971 & 11,122 & 8,154 & 8,780 & 8,561 & 9,856 & 8,221 & 10,562 & 8,709 \\
\hline Average herd SCC $(\times 1,000$ cells $/ \mathrm{mL})$ & 310 & 210 & 74 & 159 & 156 & 326 & 183 & 268 & 295 & 280 \\
\hline \multicolumn{11}{|l|}{ Udder health management } \\
\hline Gloves worn during milking & No & Yes & Yes & Yes & Yes & Yes & Yes & Yes & Yes & No \\
\hline $\begin{array}{l}\text { Postmilking teat dipping applied } \\
\text { (active component) }\end{array}$ & $\begin{array}{c}\text { Yes } \\
\text { (chlorhexidine) }\end{array}$ & $\begin{array}{c}\text { Yes } \\
\text { (iodine) }\end{array}$ & $\begin{array}{c}\text { Yes } \\
\text { (lactic acid } \\
\text { + sodium } \\
\text { chlorite) }\end{array}$ & $\begin{array}{c}\text { Yes } \\
\text { (lactic acid } \\
+ \text { sodium } \\
\text { chlorite) }\end{array}$ & $\begin{array}{c}\text { Yes } \\
\text { (iodine) }\end{array}$ & $\begin{array}{c}\text { Yes } \\
\text { (iodine) }\end{array}$ & $\begin{array}{c}\text { Yes } \\
\text { (chlorhexidine) }\end{array}$ & $\begin{array}{c}\text { Yes } \\
\text { (iodine) }\end{array}$ & $\begin{array}{c}\text { Yes } \\
\text { (lactic acid } \\
+ \text { sodium } \\
\text { chlorite) }\end{array}$ & $\begin{array}{c}\text { Yes } \\
\text { (iodine) }\end{array}$ \\
\hline \multicolumn{11}{|l|}{ Dry-cow treatment } \\
\hline Active component & Cefquinome & Cloxacillin & Cefquinome & Cloxacillin & Cefquinome & Cloxacillin & Cloxacillin & Cefquinome & Cloxacillin & Cloxacillin \\
\hline Internal teat sealer applied & Yes & Yes & Yes & Yes & Yes & Yes & No & Yes & No & Yes \\
\hline \multicolumn{11}{|l|}{ Calving pen } \\
\hline Separate straw box & Yes & Yes & Yes & Yes & Yes & Yes & Yes & Yes & Yes & Yes \\
\hline Used for sick cows & Yes & Yes & No & Yes & No & Yes & No & Yes & No & Yes \\
\hline Cleaning of slatted floor (times/d) & 2 & 2 & 6 & 2 & 2 & 2 & 6 & 2 & 2 & 1 \\
\hline \multicolumn{11}{|l|}{ Heifers included (no.) } \\
\hline Treated & 6 & 8 & 8 & 7 & 8 & 8 & 8 & 8 & 8 & 7 \\
\hline Control & 7 & 8 & 8 & 6 & 6 & 8 & 8 & 6 & 8 & 8 \\
\hline
\end{tabular}

Table 2. Binomial herd-level predictor variables constructed using data from monitoring heifers before the start of the actual clinical trial and used to screen for potential herddependent treatment effects

\begin{tabular}{|c|c|c|c|c|}
\hline Variable & $\begin{array}{l}\text { Recording } \\
\text { method }\end{array}$ & Description & Category & $\begin{array}{c}\text { Average } \\
\text { per category }\end{array}$ \\
\hline Heifers: CNS & Culture & Percentage of CNS-infected quarters of monitoring heifers & $\begin{array}{l}\text { High }(\geq 18.5 \%) \\
\text { Low }(<18.5 \%)^{1}\end{array}$ & $\begin{array}{r}20.6 \% \\
7.3 \%\end{array}$ \\
\hline Heifers: Major & Culture & Presence of major pathogens in monitoring heifers & $\begin{array}{l}\text { Presence } \\
\text { Absence }\end{array}$ & $\begin{array}{l}8.7 \% \\
0 \%\end{array}$ \\
\hline 305-d Milk yield & DHI records & Arithmetic mean 305-d milk yield of the lactating herd & $\begin{array}{l}\text { High }(\geq 8.875 \mathrm{~kg}) \\
\text { Low }(<8.875 \mathrm{~kg})^{1}\end{array}$ & $\begin{array}{l}9.956 \mathrm{~kg} \\
8.485 \mathrm{~kg}\end{array}$ \\
\hline Milk yield & DHI records & Milk yield at first test-day of the lactating heifers & $\begin{array}{l}\text { High }(\geq 25.8 \mathrm{~kg}) \\
\text { Low }(<25.8 \mathrm{~kg})^{1}\end{array}$ & $\begin{array}{l}27.8 \mathrm{~kg} \\
24.4 \mathrm{~kg}\end{array}$ \\
\hline Average heifer SCC & DHI records & Arithmetic mean test-day SCC of the lactating heifers & $\begin{array}{l}\text { High }(>150,000 \text { cells } / \mathrm{mL}) \\
\text { Low }(\leq 150,000 \text { cells } / \mathrm{mL})^{1}\end{array}$ & $\begin{array}{r}281,000 \text { cells } / \mathrm{mL} \\
99,000 \text { cells } / \mathrm{mL}\end{array}$ \\
\hline Average herd SCC & DHI records & Arithmetic mean test-day SCC of the lactating herd & $\begin{array}{l}\text { High }(>200,000 \text { cells } / \mathrm{mL}) \\
\text { Low }(\leq 200,000 \text { cells } / \mathrm{mL})^{1}\end{array}$ & $\begin{array}{l}281,000 \text { cells } / \mathrm{mL} \\
143,000 \text { cells } / \mathrm{mL}\end{array}$ \\
\hline Presence of penicillin resistance & Etest $^{2}$ & Susceptibility to penicillin of staphylococcal isolates & $\begin{array}{l}\text { Presence } \\
\text { Absence }\end{array}$ & $\begin{array}{l}24 \% \\
0 \%\end{array}$ \\
\hline Hygiene of herd & Visual & Percentage of unclean monitoring heifers & $\begin{array}{l}\text { Unclean }(\geq 37.5 \%) \\
\text { Clean }(<37.5 \%)^{1}\end{array}$ & $\begin{array}{l}65.6 \% \\
27.1 \%\end{array}$ \\
\hline
\end{tabular}

${ }^{1}$ Categorization based on median value.

${ }^{2}$ AB Biodisk (Solna, Sweden). 
cocci. Colony morphology, hemolysis patterns, and DNase testing were used to distinguish Staph. aureus from CNS. Streptococci were subdivided into esculin-positive streptococci (Streptococcus uberis) and esculin-negative streptococci (Streptococcus agalactiae and Streptococcus dysgalactiae). Differentiation between Strep. uberis and other streptococci was done using bile esculin agar and $\mathrm{NaCl}$ 6.5\%. The Christie, Atkins, MunchPetersen (CAMP) test was used to differentiate Strep. agalactiae from Strep. dysgalactiae. Coliforms including Escherichia coli, Klebsiella spp., and Enterobacter spp. were differentiated from each other and from other gram-negative bacteria based on the appearance on MacConkey agar, $\mathrm{KOH}$ testing, triple sugar iron reactions, indole production, and motility. Staphylococcus aureus, esculin-positive streptococci, Strep. agalactiae, Strep. dysgalactiae, and coliforms were considered as major pathogens, whereas CNS and Corynebacterium bovis were considered as minor pathogens.

Penicillin Resistance. All staphylococci were tested by the Etest method (AB Biodisk, Solna, Sweden), a stable-gradient agar diffusion technique that produces quantitative MIC results over a $15 \log _{2}$ dilution range (Brown and Brown, 1991). Isolates were defined as susceptible to penicillin G when the MIC was $\leq 0.125$ $\mathrm{mg} / \mathrm{L}$ and as resistant to penicillin $\mathrm{G}$ when the MIC was $>0.125 \mathrm{mg} / \mathrm{L}$, respectively (EUCAST, 2011).

$S C \boldsymbol{C}$. Milk SCC was quantified by electronic counting using a Fossomatic 5000 (Foss Electric, Hillerød, Denmark) at the Milk Control Centre Flanders (Lier, Belgium).

Antimicrobial Residues. Before delivering milk (2-4 DIM), farmers tested all treated heifers as required by the Dairy Quality Assurance scheme with a Delvo test (Angelidis et al., 1999). No residues were detected in any of the samples.

\section{Definition of Subclinical and Clinical Mastitis}

A quarter was considered subclinically infected in early lactation (0-3 DIM) when, in the absence of clinical symptoms, the same udder pathogen was isolated from both duplicate milk samples (Borm et al., 2006). A quarter was considered as noninfected when no pathogens were isolated from either duplicate milk sample. When an udder pathogen was isolated in only one sample from duplicate milk samples or when one or both milk samples were contaminated, the data were considered missing.

Clinical mastitis was recorded by the first author or the farmer, or both, and was defined as the presence of visual signs such as clots in the milk, with or without redness, swelling of the udder quarter, or systemic signs. The interval between cases of CM in the same quarter had to be $\geq 14 \mathrm{~d}$ to be included in the analysis as a new CM case (Barkema et al., 1998). All CM were treated by the farmer according to the each farm's treatment protocol.

\section{Herd-Level Predictor Variables}

As aforementioned, several binomial herd-level predictor variables were constructed using the data gathered from the monitoring heifers $(\mathrm{n}=80)$ before the start of the actual clinical trial (Table 2). These variables were used to screen for potential herd-dependent treatment effects. The distribution of these herd-level predictor variables over the different herds is shown in Table 3. Hygiene scores ranging from 1 (clean) to 5 (dirty) were assigned for 4 body areas: tail head, thigh, udder, and hind limbs (Hughes, 2001). Heifers with an average cleanliness score $\leq 2.0$ (median value of all herd averages) were considered clean and heifers with a cleanliness score $>2.0$ were considered unclean.

\section{Statistical Analyses}

Before statistical analysis, observations were explored and checked for unlikely values. No data were excluded for this reason. Milk SCC was transformed to the natural logarithmic scale (LnSCC) to normalize the data. Significance level was set at $P<0.05$.

In general, 8 different outcome variables were used. Outcomes in early lactation (0-3 DIM) were likelihood of IMI due to any pathogen, due to major pathogens only, or due to CNS only, and prevalence of CM. Outcomes in late lactation (4-120 DIM) were LnSCC at test-day, MY at test-day, incidence of $\mathrm{CM}$, and culling. For 5 of the 8 outcome variables (likelihood of IMI in early lactation due to any pathogen, major pathogens only, or CNS only; LnSCC and MY at test-day) separate models were fitted using a common approach including the following predictor variables: treatment (yes vs. no), 1 of the 8 binomial herd-level predictor variables (Table 2), and the interaction between treatment and the included herd-level predictor variable. Each of the 8 binomial herd-level predictor variables (Table 2) was added to each model, and then removed and replaced by the next one, which eventually resulted in 8 separate models per outcome variable. The models were reduced if the interaction term was not significant $(P>0.05)$. The association between treatment (yes vs. no) and the likelihood of IMI at the quarter level with any pathogen, major pathogens only, or CNS only in early lactation as the different outcome variables was analyzed by means of logistic mixed regression models using first-order marginal quasi-likelihood algorithms (MLwiN 2.16; Centre for Multilevel Modeling, Bristol, 
UK). In each model, heifer and herd were included as random effects to correct for clustering of quarters within heifers and heifers within herds. The association between treatment (yes vs. no) and MY and SCC at test-day during the first 120 DIM, respectively, were analyzed using mixed models (version 9.1.3; SAS Institute Inc., Cary, NC) with test-day MY (kg) and LnSCC as outcome variables. Herd and heifer were included as random effects to correct for clustering of heifers within herds and repeated measurements within heifers. An autoregressive (1) covariance structure was included to model the repeated measurements within heifers. Because of the repeated measurements, DIM (continuous) at test day and the quadratic effect of DIM were included in the models besides the aforementioned predictor variables.

The association between treatment (yes versus no) and prevalence of $\mathrm{CM}$ in early lactation (0-3 DIM), incidence of CM in later lactation (4-120 DIM), and culling in later lactation, respectively, were examined using contingency tables and $\chi^{2}$ analysis. Correction for clustering of heifers within herds was not feasible because of the limited number of events. For the same reason, herd predictors and their interaction with treatment were not tested.

To compare antimicrobial susceptibility of staphylococcal isolates cultured from milk collected in early lactation (subclinical samples) from treated and control heifers, survival curves of both groups were plotted using a Kaplan-Meier survival analysis (SPSS version 19.0., SPSS Inc., Chicago, IL), with the MIC values defined as the time-to-event (Sampimon et al., 2011). When isolates were killed below the lowest test concentration or were still growing at the highest test concentration, observations were coded as left or right censored, respectively. The Logrank test was used to test for significant differences in survival between the 2 groups of isolates $(P<0.05)$.

\section{RESULTS}

\section{Descriptive Results}

In total, 149 heifers (596 quarters), comprising 76 treated heifers (304 quarters) and 73 control heifers (292 quarters), were included in the clinical trial. The target of 80 heifers in each group was not met because herd sizes were sometimes not sufficient to reach the required number of heifers within the specified time frame.

Overall, in early lactation, 347 quarters were noninfected, 34 had an IMI with a major pathogen, and 94 had an IMI with CNS (Table 4). Samples from 37 quarters were contaminated and, in 84 quarters, assignment 
Table 4. Quarter-level prevalence of IMI in early lactation (0-3 DIM) and distribution of pathogens from the heifers sampled before the onset of the clinical trial (monitoring) as well as from the heifers included in the clinical trial, either systemically treated prepartum with penethamate hydriodide (treated) or left untreated (control)

\begin{tabular}{|c|c|c|c|c|c|c|c|}
\hline Infection status (quarter level) & \multicolumn{2}{|c|}{ Monitoring } & \multicolumn{2}{|c|}{ Treated } & \multicolumn{2}{|c|}{ Control } & $P$-value ${ }^{2}$ \\
\hline Noninfected & 168 & 52.5 & 187 & 61.5 & 160 & 54.8 & \\
\hline Subclinically infected with major pathogens & 27 & 8.4 & 14 & 4.6 & 20 & 6.8 & 0.173 \\
\hline Staphylococcus aureus & 6 & & 1 & & 5 & & \\
\hline Streptococcus uberis & 9 & & 6 & & 4 & & \\
\hline Escherichia coli & 8 & & 2 & & 2 & & \\
\hline Subclinically infected with minor pathogens & 68 & 21.3 & 42 & 13.3 & 57 & 18.6 & \\
\hline CNS & 65 & 20.3 & 40 & 13.1 & 54 & 18.5 & 0.053 \\
\hline Other (Bacillus spp., Corynebacterium bovis) & 3 & $<1$ & 2 & $<1$ & 3 & $<1$ & \\
\hline Contaminated & 23 & 7.2 & 19 & 6.2 & 18 & 6.2 & \\
\hline Missing values & 34 & 10.6 & 44 & 14.4 & 40 & 13.6 & \\
\hline Total & 320 & & 304 & & 292 & & \\
\hline
\end{tabular}

${ }^{1}$ Percentage of total quarters sampled.

${ }^{2} P$-value from logistic mixed regression models with herd and heifer as random effect comparing odds of quarters subclinically infected with any pathogen, major pathogens only, or CNS only, respectively, versus noninfected quarters from treated and control heifers.

of an IMI status was impossible (all data were encoded as missing values). In total, 128 quarters had an IMI with a major pathogen or with CNS (Table 4). In addition, 6 heifers suffered from a CM at calving (4\%). All $(\mathrm{n}=12)$ of the Staph. aureus isolates and $73 \%(\mathrm{n}=$ 143) of the CNS isolates originating from milk samples taken in early lactation during the treatment trial were susceptible to penicillin.

The overall average SCC on the first test-day was 290,221 cells $/ \mathrm{mL}(\mathrm{SD}=725,521)$ and decreased to 122,000 cells $/ \mathrm{mL}(\mathrm{SD}=338,819)$ on the fourth testday. Average milk production started at $27.0 \mathrm{~kg} / \mathrm{d}(\mathrm{SD}$ $=5.9)$ on the first test-day, increased to $30.2 \mathrm{~kg} / \mathrm{d}(\mathrm{SD}$ $=5.6)$ and reached $27.7 \mathrm{~kg}(\mathrm{SD}=5.3)$ on the fourth test-day. Thirteen heifers developed a case of CM during their first 120 DIM, whereas 7 heifers were culled during that period ( 1 because of mastitis issues).

\section{Treatment Effects}

In all herds, quarters from penethamate-treated heifers were significantly less likely to have an IMI in early lactation with any pathogen $(P=0.023)$. A trend toward fewer IMI with CNS was also noted $(P$ $=0.053$; Table 4 ). The likelihood of IMI with a major pathogen did not differ between treated and nontreated heifers $(P=0.17)$. None of the herd-level predictors or interactions with treatment was significant, indicating that treatment effects were not modified by any of the studied herd-level predictor variables. All 6 cases of $\mathrm{CM}$ in early lactation occurred in the treatment group: Strep. uberis $(\mathrm{n}=1), C$. bovis $(\mathrm{n}=1)$, and Staph. aureus $(\mathrm{n}=1)$ were isolated; 1 sample was contaminated; and 2 samples remained culture negative. Seventy one percent $(\mathrm{n}=60)$ and $74 \%(\mathrm{n}=83)$ of all Staphylococcus isolates recovered from milk samples from the control and treated heifers in early lactation, respectively, were susceptible to penicillin $(P>0.05$; Figure 1$)$.

Treatment did not influence LnSCC at test-day during the first 120 DIM $(P=0.85$; Figure 2, Table 5$)$. None of the herd-level predictor variables or interaction terms were significant and therefore omitted from the final models. Treatment did not influence test-day MY

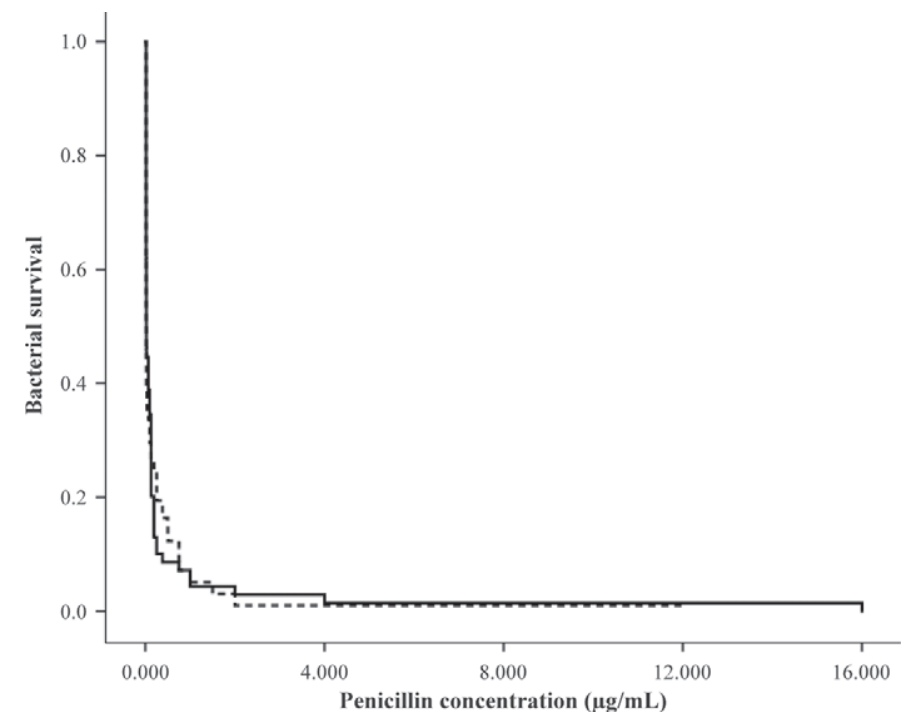

Figure 1. Proportion of staphylococcal isolates surviving with increasing concentrations of penicillin, cultured from samples taken at calving from control (---) and treated $(-)$ heifers $(P=0.81)$. 
Table 5. Overview of data on udder health, milk production and culling hazard of the dairy heifers included in the clinical trial either systemically treated prepartum with penethamate hydriodide (treated) or untreated (control) in later lactation (4 to 120 DIM)

\begin{tabular}{|c|c|c|c|c|c|c|c|c|}
\hline \multirow[b]{2}{*}{ Herd } & \multicolumn{2}{|c|}{$\begin{array}{l}\text { Average test-day } \mathrm{LnSCC}^{1} \\
(\times 1,000 \text { cells } / \mathrm{mL})\end{array}$} & \multicolumn{2}{|c|}{$\begin{array}{l}\text { Average test-day } \\
\text { milk yield }^{1}(\mathrm{~kg})\end{array}$} & \multicolumn{2}{|c|}{ CM (no.) } & \multicolumn{2}{|c|}{$\begin{array}{l}\text { Culling for all } \\
\text { reasons }{ }^{2} \text { (no.) }\end{array}$} \\
\hline & Treated & Control & Treated & Control & Treated & Control & Treated & Control \\
\hline 1 & 5.00 & 4.71 & 31.0 & 29.1 & 0 & 0 & 0 & 1 \\
\hline 2 & 4.99 & 4.62 & 26.5 & 29.6 & 2 & 3 & 2 & 0 \\
\hline 3 & 3.70 & 4.10 & 33.7 & 33.7 & 0 & 0 & 0 & 0 \\
\hline 4 & 5.10 & 5.02 & 27.4 & 24.1 & 0 & 0 & 1 & 0 \\
\hline 7 & 4.59 & 4.15 & 30.2 & 30.9 & 1 & 0 & 0 & 0 \\
\hline 8 & 4.77 & 4.69 & 29.8 & 29.2 & 3 & 1 & 1 & 0 \\
\hline 9 & 3.94 & 4.67 & 25.5 & 28.3 & 0 & 0 & 2 & 0 \\
\hline 10 & 4.61 & 4.75 & 31.1 & 26.8 & 1 & 0 & 0 & 0 \\
\hline Total & 4.56 & $4.57^{3}$ & 31.0 & $29.2^{4}$ & 8 & $5^{5}$ & 6 & $1^{6}$ \\
\hline
\end{tabular}

${ }^{1}$ Least squares means based on models including herd and herd $\times$ treatment interaction as fixed effects.

${ }^{2}$ Denotes that the heifer was culled because of mastitis (indicated culling reason).

${ }^{3}$ Differences between treated and control heifers was not significant $(P=0.85)$.

${ }^{4}$ Differences between treated and control heifers was not significant $(P=0.87)$.

${ }^{5}$ Differences between treated and control heifers was not significant $(P=0.63)$.

${ }^{6}$ The model evaluating whether numbers were statistically different did not converge because only 1 heifer was culled due to mastitis.

during the first 120 DIM $(P=0.87$; Table 5$)$. None of the herd-level predictor variables was significant, although one interaction term was (MY heifers $\times$ treatment; $P=$ $0.02)$. Penethamate-treated heifers from herds classified as having low-yielding heifers out-produced untreated animals $(+2.2 \mathrm{~kg}$ of milk/day; $P=0.07)$, whereas in herds classified as having high-yielding heifers, milk production was $1.5 \mathrm{~kg}$ of milk/day lower in treated heifers compared with the controls $(P=0.14$; Figure 3$)$. Also, treatment tended to be associated with a higher test-day MY in farms with a high average herd SCC than on farms with a low average herd SCC (average herd SCC $\times$ treatment; $P=0.08)$.

Five $(6.8 \%)$ control heifers developed a case of $\mathrm{CM}$ between 4 to 120 DIM, whereas $8(10.5 \%)$ treated heifers suffered from a case of CM (uncorrected $\chi^{2}=0.21$; $P=0.63$; Table 5 ). In the control group, only 1 heifer was culled (because of mastitis), whereas in the treatment group, 6 heifers were culled, but none of them because of mastitis issues: 3 heifers were culled because of trauma, 2 because of nonfunctional quarters, and 1 because of claw disorders (Table 5).

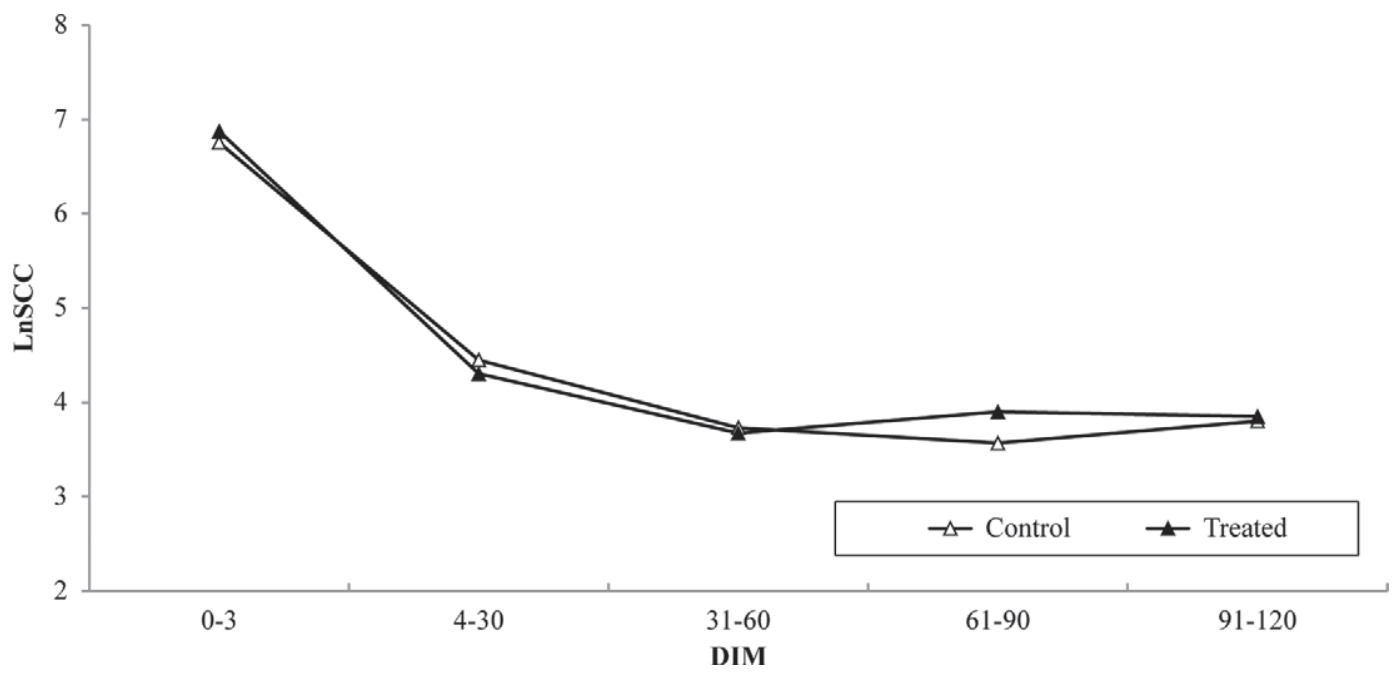

Figure 2. Average milk SCC transformed to the natural logarithmic scale (LnSCC) in heifers systemically treated prepartum with penethamate hydriodide and control heifers during 120 DIM $(P=0.85)$. 


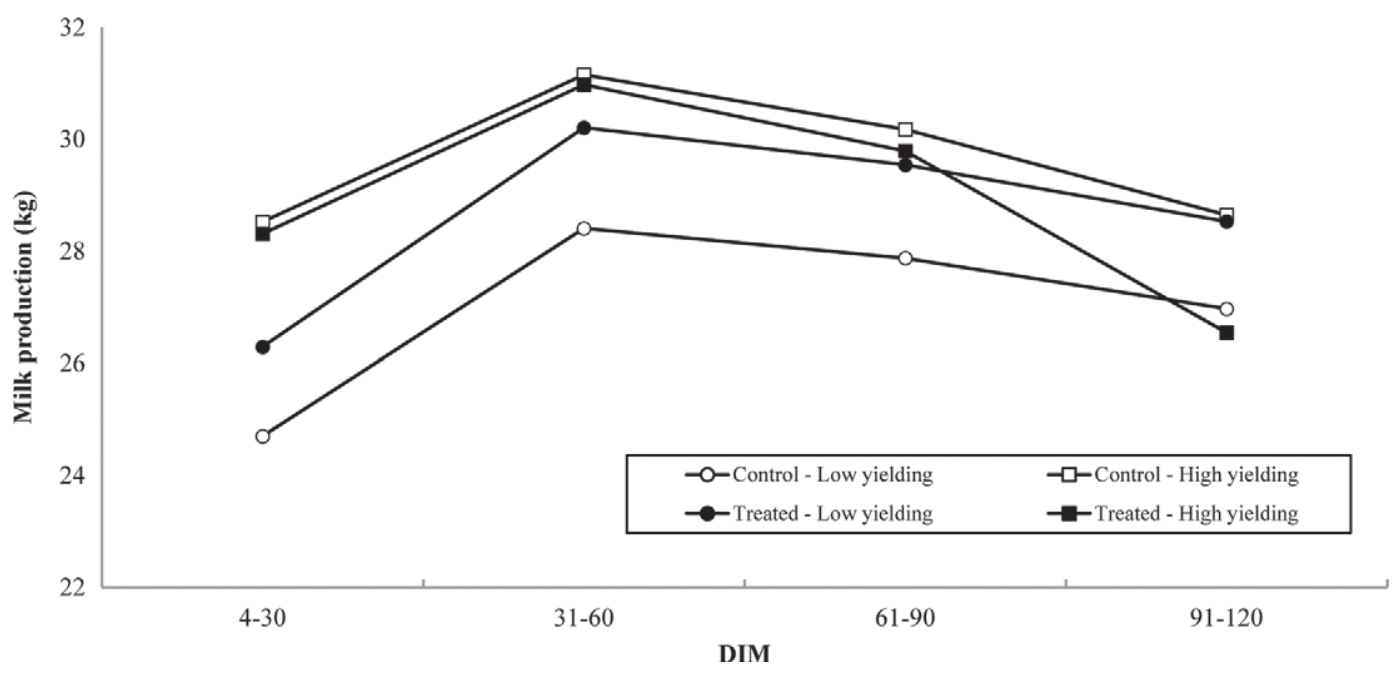

Figure 3. Test-day milk production $(\mathrm{kg} / \mathrm{d})$ in heifers systemically treated prepartum with penethamate hydriodide and control heifers during 120 DIM in herds categorized as having either low-yielding heifers or high-yielding heifers (interaction term; $P=0.02$ ).

\section{DISCUSSION}

Prevalence of IMI with any pathogen was $25.3 \%$ at the quarter level in the control group, which was within the range of 12 to $>57 \%$ stated by De Vliegher et al. (2012) in reviewing several different studies. The majority of IMI were caused by CNS, substantiating the finding of most other studies, whereas IMI with major pathogens were in the minority. The sole fact that CNS infections are abundantly present in milk samples from heifers at calving should not be interpreted as if a heifer mastitis problem exists because their effect on future performances is limited or even absent (Compton et al., 2007; Piepers et al., 2010, 2013).

From a practical standpoint, the administration of antimicrobials to end-term heifers by the systemic route is to be preferred over intramammary infusion (Nickerson, 2009). However, it has been questioned whether subcutaneous or intramuscular injection of drugs can actually cure IMI in bred heifers because insufficient concentrations of the antimicrobial might reach the mammary gland (Nickerson, 2009). This is probably the first field trial to demonstrate that the mammary gland has been reached by penethamate hydriodide, because the systemic prepartum treatment was associated with significantly less IMI with both CNS and any pathogen in early lactation. This substantiates our previous work showing that substantially higher levels of penicillin $\mathrm{G}$ than the $\mathrm{MIC}_{90}$ of pathogens associated with heifer mastitis were reached in udder tissue and mammary secretions from heifers systemically treated with penethamate hydriodide before calving (Passchyn et al., 2010). Still, our findings were in contrast with those reported by Parker et al. (2008), who found that systemic treatment of end-term heifers with tylosin $27 \mathrm{~d}$ before calving did not reduce the prevalence of IMI postcalving. All other studies on prepartum use of antimicrobials in the prevention of heifer mastitis that showed a significant decrease in IMI after treatment were performed using either short-acting (Oliver et al., 1992, 2004; Middleton et al., 2005; Borm et al., 2006; Roy et al., 2007) or long-acting intramammary preparations (Trinidad et al., 1990b; Owens et al., 1991, 1994; Sampimon et al., 2009).

Surprisingly, all 6 cases of CM in early lactation occurred in the treatment group. Several of those CM might have been caused by gram-negative bacteria. In those cases, we would have anticipated no effect of a penethamate treatment. Iatrogenic infections by treatment as observed by Deluyker et al. (2005) could be excluded because no local treatment was applied in this study. Because not all CM cases are a function of prepartum IMI and no antimicrobial residues were detected in the milk, which means that penethamate hydriodide was not active at therapeutic levels in the mammary gland at calving, the higher incidence of $\mathrm{CM}$ in the treatment group could also be the result of chance. However, one could speculate that treatment with penethamate disturbed the microflora in the udder (Oikonomou et al., 2012), making the quarters of treated animals more susceptible to environmental bacteria, although this needs further study.

From an economical point of view, positive long-term treatment effects are needed to support prepartum treatment of end-term heifers. Apart from one specific effect, no overall positive long-term effects (4 to 120 DIM) were detected during our trial. The latter observation is in contrast to the results reported by 
several other research groups (Trinidad et al., 1990b; Owens et al., 1991, 1994; Oliver et al., 2003; Sampimon et al., 2009) applying long-acting intramammary preparations, but agrees with the findings of Borm et al. (2006), who used a short-acting intramammary preparation. As intramammary treatment with shortacting preparations and systemic injection(s) have only a short period of curative or preventative action, those findings are probably not that surprising; long-acting intramammary preparations, on the other hand, are expected to result in high drug concentrations in the mammary tissue over several weeks.

Moreover, the herds included in the studies that reported a positive effect of prepartum treatment on MY had a high prevalence of major pathogen IMI and a history of heifer mastitis problems (Kreiger et al., 2007; Bryan and Taylor, 2009; Sampimon et al., 2009). Some trials were conducted on research farms (Oliver et al., 1992, 2004; Owens et al., 1994) or on farms having (suspected) heifer mastitis problems (Kreiger et al., 2007; Bryan and Taylor, 2009; Sampimon et al., 2009). The fact that none of the herds included in our study actually suffered from a heifer mastitis issue probably explains why no overall beneficial long-term treatment effects (from 4 to 120 DIM) were detected. Our findings confirm again that the sole fact of a high proportion of heifers or quarters infected with CNS in early lactation should not be a concern. In that respect, analysis of the data from the nontreated heifers only in a recent study (Piepers et al., 2013) substantiated a previously described positive association between CNS IMI and milk yield (Piepers et al., 2010).

Given the conclusions of previous studies (Borm et al., 2006; Bryan and Taylor, 2009), our trial was specifically designed in anticipation of potential herd-specific treatment effects by including a monitoring period in the study before the onset of the actual treatment trial. This novel approach allowed us to determine that treated heifers in herds classified as having low-yielding heifers out-produced the control heifers. We hypothesized that the positive effect of prepartum treatment of heifers 2 wk before calving could depend on management. It is indeed well established that treatment of subclinical mastitis is more effective in well-managed than in poorly managed herds, where cured cows or heifers are more likely to become re-infected (Barlow et al., 2009). Assuming that the milk production of heifers in our study reflects management, the latter hypothesis could not be substantiated and our data even suggest the opposite, all the more so because treatment tended to be more beneficial in high-SCC herds than in low-SCC herds. Still, none of the other herd-level predictors specifically reflecting the farmers' style of heifer management, such as SCC of fresh heifers and hygiene of the heifers, modified the treatment effect in a similar way, leaving a precise explanation of the finding unknown. Based on the herd predictor that encoded for the presence of major pathogens, the hypothesis put forward by Barlow et al. (2009) could not be substantiated either. Still, caution should be taken when reaching conclusions because the prevalence of IMI with major pathogens was low in our study. Although the herdlevel predictors were selected based on their biological relevance and practical feasibility, studying 8 of them when only including 10 herds might have resulted in finding a significant association by coincidence.

Given the concerns that antimicrobial overuse in food animal production has the potential to increase antimicrobial resistance in human pathogens, alternative strategies to widespread antimicrobial use are needed (FAO/WHO/OIE, 2007; Silbergeld et al., 2008). In that respect, prepartum treatment of end-term heifers, when heifers are not producing milk, would only be defensible if it would prevent additional treatments during lactation (when milk is being produced as a marketable product and treatment would reduce animal welfare issues caused by $\mathrm{CM}$ ). In addition, treatment of end-term heifers constitutes extra-label use in many countries, which obviously has implications for the withholding times of meat and milk. One could hypothesize that selection toward resistant commensals (such as CNS) is more likely to occur when systemic treatment is being used. In our study, treatment did not increase the likelihood of penicillin resistance in staphylococci (of which a majority were CNS) isolated in milk samples at calving. However, selection and spread of resistance takes time, making it difficult to reach a conclusion on this issue. Without over-interpreting the data and in light of antimicrobial resistance, the use of short-acting antimicrobials (intramammary and parenteral use) with a narrow spectrum should be preferred in those herds that suffer from a true heifer mastitis problem and that are hence likely to profit from treatment.

\section{CONCLUSIONS}

Systemic therapy of end-term heifers with penethamate hydriodide 2 wk before calving resulted in fewer IMI at the quarter level in early lactation on the one hand but in more cases of CM in the first days after calving (0-3 DIM) on the other hand. Overall longterm effects (4-120 DIM) of penethamate treatment on milk production, udder health, or culling hazard during later lactation were not detected. Still, using the data from the monitoring period, we showed that penethamate-treated heifers from herds classified as having low-yielding heifers out-produced control heifers. Treatment of end-term heifers was not associated 
with the development of penicillin resistance in staphylococci isolated from milk samples in the short term. Prepartum systemic antimicrobial treatment is not warranted in herds with low prevalence of heifer mastitis. A similar study conducted on commercial farms with a high prevalence of heifer mastitis is required to further examine the outcomes of this trial.

\section{ACKNOWLEDGMENTS}

This study was funded by Boehringer Ingelheim Animal Health (Ingelheim, Germany). The authors thank the herd managers for participating in the study and for their assistance. Milk Control Center Flanders (Lier, Belgium) is acknowledged for performing all laboratory analyses.

\section{REFERENCES}

Angelidis, A. S., T. B. Farver, and J. S. Cullor. 1999. Evaluation of the Delvo-X-Press assay for detecting antibiotic residues in milk samples from individual cows. J. Food Prot. 62:1183-1190.

Barkema, H. W., Y. H. Schukken, T. J. G. M. Lam, M. L. Beiboer, H. Wilmink, G. Benedictus, and A. Brand. 1998. Incidence of clinical mastitis in dairy herds grouped in three categories by bulk milk somatic cell counts. J. Dairy Sci. 81:411-419.

Barlow, J. W., L. J. White, R. N. Zadoks, and Y. H. Schukken. 2009 A mathematical model demonstrating indirect and overall effects of lactation therapy targeting subclinical mastitis in dairy herds. Prev. Vet. Med. 90:31-42.

Borm, A. A., L. K. Fox, K. E. Leslie, J. S. Hogan, S. M. Andrew, S. P. Oliver, Y. H. Schukken, D. D. Hancock, C. T. Gaskins, W. E Owens, and C. Norman. 2006. Effects of prepartum intramammary antibiotic therapy on udder health, milk production, and reproductive performance in dairy heifers. J. Dairy Sci. 89:2090-2098.

Brown, D. F. J., and L. Brown. 1991. Evaluation of the Etest: A novel method of quantifying antimicrobial activity. J. Antimicrob. Chemother. 27:185-190.

Bryan, M., and K. Taylor. 2009. Periparturient use of parenteral micronised procaine penicillin to reduce the risk of clinical mastitis in heifers after calving. Vet. Microbiol. 134:143-149.

Compton, C. W. R., C. Heuer, K. Parker, and S. McDougall. 2007. Epidemiology of mastitis in pasture-grazed peripartum dairy heifers and its effects on productivity. J. Dairy Sci. 90:4157-4170.

De Vliegher, S., H. W. Barkema, G. Opsomer, A. de Kruif, and L. Duchateau. 2005a. Association between somatic cell count in early lactation and culling of dairy heifers using Cox frailty models. J. Dairy Sci. 88:560-568.

De Vliegher, S., H. W. Barkema, H. Stryhn, G. Opsomer, and A. de Kruif. 2004. Impact in dairy heifers of early lactation somatic cell count on somatic cell counts during the first lactation. J. Dairy Sci. 87:3672-3682.

De Vliegher, S., H. W. Barkema, H. Stryhn, G. Opsomer, and A. de Kruif. 2005b. Impact of early lactation somatic cell count in heifers on milk yield over the first lactation. J. Dairy Sci. 88:938-947.

De Vliegher, S., L. K. Fox, S. Piepers, S. McDougall, and H. W. Barkema. 2012. Invited review: Mastitis in dairy heifers. J. Dairy Sci. 95:1025-1040.

Deluyker, H. A., S. N. Van Oye, and J. F. Boucher. 2005. Factors affecting cure and somatic cell count after pirlimycin treatment of subclinical mastitis in lactating cows. J. Dairy Sci. 88:604-614.

Erskine, R. J. 2006. Overview of literature on antimicrobial resistance of mastitis pathogens. Pages 3-9 in Proc. 45th Annu. Mtg. National Mastitis Counc. Natl. Mastitis Counc., Madison, WI.
EUCAST. 2011. Clinical Breakpoint Table. Accessed June 1, 2012. http://www.eucast.org/antimicrobial_susceptibility_testing/ previous_versions_of_tables/.

FAO/WHO/OIE. 2007. Report of the Joint FAO/WHO/OIE expert meeting on critically important antimicrobials. Rome, Italy, November 26-30, 2007. Accessed June 1, 2012. http://www.who.int/ foodborne_disease/resources/Report\%20joint\%20CIA\%20Meeting .pdf.

Fox, L. K. 2009. Prevalence, incidence and risk factors of heifer mastitis. Vet. Microbiol. 134:82-88.

Hughes, J. 2001. A system for assessing cow cleanliness. In Pract. 23:517-524.

Huijps, K., S. De Vliegher, T. Lam, and H. Hogeveen. 2009. Cost estimation of heifer mastitis in early lactation by stochastic modeling. Vet. Microbiol. 134:121-127.

Johnston, A. M. 1998. Use of antimicrobial drugs in veterinary practice. BMJ 317:665-667.

Kreiger, M., G. Friton, J. Hofer, K. Fuchs, and P. Winter. 2007. Effects of periparturient systemic treatment with penethamate hydriodide on udder health and milk yield of dairy heifers. J. Dairy Res. 74:392-398.

Middleton, J. R., L. L. Timms, R. Bader, J. Lakritz, C. D. Luby, and B. J. Steevens. 2005. Effect of prepartum intramammary treatment with pirlimycin hydrochloride on prevalence of early first-lactation mastitis in dairy heifers. J. Am. Vet. Med. Assoc. 227:1969-1974.

Nickerson, S. C. 2009. Control of heifer mastitis: Antimicrobial treatment-An overview. Vet. Microbiol. 134:128-135.

Oikonomou, G., V. S. Machado, C. Santisteban, Y. H. Schukken, and R. C. Bicalho. 2012. Microbial diversity of bovine mastitic milk as described by pyrosequencing of metagenomic 16s rDNA. PLoS ONE 7:e47671.

Oliver, S. P., B. E. Gillespie, S. J. Ivey, M. J. Lewis, D. L. Johnson, K C. Lamar, H. Moorehead, H. H. Dowlen, S. T. Chester, and J. W Hallberg. 2004. Influence of prepartum pirlimycin hydrochloride or penicillin-novobiocin therapy in mastitis in heifers during early lactation. J. Dairy Sci. 87:1727-1731.

Oliver, S. P., M. J. Lewis, B. E. Gillespie, and H. H. Dowlen. 1992. Influence of prepartum antibiotic therapy on intramammary infections in primigravid heifers during early lactation. J. Dairy Sci. 75:406-414.

Oliver, S. P., M. J. Lewis, B. E. Gillespie, H. H. Dowlen, E. C. Jaenicke, and R. K. Roberts. 2003. Prepartum antibiotic treatment of heifers: Milk production, milk quality and economic benefit. J. Dairy Sci. 86:1187-1193.

Oliver, S. P., and B. A. Mitchell. 1983. Intramammary infections in primigravid heifers near parturition. J. Dairy Sci. 66:1180-1183.

Owens, W. E., S. C. Nickerson, R. L. Boddie, G. M. Tomita, and C. H. Ray. 2001. Prevalence of mastitis in dairy heifers and effectiveness of antibiotic therapy. J. Dairy Sci. 84:814-817.

Owens, W. E., S. C. Nickerson, P. J. Washburn, and C. H. Ray. 1991. Efficacy of a cephapirin dry cow product for treatment of experimentally induced Staphylococcus aureus mastitis in heifers. J. Dairy Sci. 74:3376-3382.

Owens, W. E., S. C. Nickerson, P. J. Washburn, and C. H. Ray. 1994 Prepartum antibiotic-therapy with a Cephapirin dry-cow product against naturally-occurring intramammary infections in heifers. Zentralbl. Veterinarmed. B 41:90-100.

Parker, K. I., C. W. Compton, F. M. Anniss, C. Heuer, and S. McDougall. 2008. Quarter-level analysis of subclinical and clinical mastitis in primiparous heifers following the use of a teat sealant or an injectable antibiotic, or both, precalving. J. Dairy Sci. 91:169-181.

Parker, K. I., C. W. Compton, F. M. Anniss, A. M. Weir, and S. McDougal. 2007. Management of dairy heifers and its relationships with the incidence of clinical mastitis. N. Z. Vet. J. 55:208-216.

Passchyn, P., S. Piepers, E. Schmitt, C. Guidarini, and S. De Vliegher. 2010. Concentration of penicillin G in mammary tissue and secretion of end-term dairy heifers following systemic prepartum administration of penethamate hydriodide. J. Dairy Res. 77:33-36.

Piepers, S., L. De Meulemeester, A. de Kruif, G. Opsomer, H. W. Barkema, and S. De Vliegher. 2007. Prevalence and distribution of 
mastitis pathogens in subclinically infected dairy cows in Flanders, Belgium. J. Dairy Res. 74:478-483.

Piepers, S., S. De Vliegher, A. de Kruif, G. Opsomer, and H. W. Barkema. 2009. Impact of intramammary infections in dairy heifers on future udder health, milk production, and culling. Vet. Microbiol. 134:113-120.

Piepers, S., G. Opsomer, H. W. Barkema, A. de Kruif, and S. De Vliegher. 2010. Heifers infected with coagulase-negative staphylococci in early lactation have fewer cases of clinical mastitis and higher milk production in their first lactation than non-infected heifers. J. Dairy Sci. 93:2014-2024.

Piepers, S., Y. H. Schukken, P. Passchyn, and S. De Vliegher. 2013. The impact of intramammary infection with coagulase-negative staphylococci in early lactating heifers on milk yield throughout first lactation revisited. J. Dairy Sci. 96:5095-5105.

Roberson, J. R., L. K. Fox, D. D. Hancock, J. M. Gay, and T. E. Besser. 1994. Coagulase-positive Staphylococcus intramammary infections in primiparous dairy cows. J. Dairy Sci. 77:958-969.

Roy, J. P., D. Du Tremblay, L. Descôteaux, S. Messier, D. Scholl, and E. Bouchard. 2007. Effect of precalving intramammary treatment with pirlimycin in nulliparous Holstein heifers. Can. J. Vet. Res. 71:283-291.

Sampimon, O. C., S. De Vliegher, H. W. Barkema, J. Sol, and T. J. G. M. Lam. 2009. Effect of prepartum dry cow antibiotic treatment in dairy heifers on udder health and milk production. J. Dairy Sci. 92:4395-4403.

Sampimon, O. C., T. J. G. M. Lam, D. J. Mevius, Y. H. Schukken, and R. N. Zadoks. 2011. Antimicrobial susceptibility of coagulasenegative staphylococci isolated from bovine milk samples. Vet. Microbiol. 150:173-179.

Silbergeld, E. K., J. Graham, and L. B. Price. 2008. Industrial food animal production, antimicrobial resistance, and human health. Annu. Rev. Public Health 29:151-169.

Trinidad, P., S. C. Nickerson, and T. K. Alley. 1990a. Prevalence of intramammary infection and teat canal colonization in unbred and primigravid dairy heifers. J. Dairy Sci. 73:107-114.

Trinidad, P., S. C. Nickerson, T. K. Alley, and R. W. Adkinson. 1990b. Efficacy of intramammary treatment in unbred and primigravid dairy heifers. J. Am. Vet. Med. Assoc. 197:465-470. 